The use of remote sensing, regression quantiles ... (I Nyoman Radiarta)

\title{
THE USE OF REMOTE SENSING, REGRESSION QUANTILES, AND GIS APPROACHESFOR MODELING OF SCALLOP LARVAE: A Case Study in Funka Bay, Hokkaido, Japan
}

\author{
I Nyoman Radiarta\# \\ Center for Aquaculture Research and Development
}

(Received 5 June 2011; Accepted 11 September 2011)

\begin{abstract}
In the development of scallop cultivation in Japan, larvae collection and propagation become an important factor. Although the monitoring program has been conducted, modeling of species distribution is becoming an important tool for understanding the effects of environmental changes and resources management. This study was conducted to construct a model for providing estimation of the scallop larvae distribution in Funka Bay, Hokkaido, Japan using the integration of remote sensing, Regression Quantile (RQ) and Geographic Information System (GIS)- based model. Data on scallop larvae were collected during one year spawning season from April to July 2003. Environmental parameters were extracted from multi sensor remotely sensed data (chlorophyll- a and sea surface temperature) and a hydrographic chart (water depth). These parameters together with larvae data were then analyzed using RQ. Finally, spatial models were constructed within a GIS by combining the RQ models with digital map of environmental parameters. The results show that the model was best explained by using only sea surface temperature. The highest larvae densities were predicted in a relatively broad distribution along with the shallow water regions (Toyoura and Sawara to Yakumo) and the deeper water areas (center of the bay). The spatial model built from the RQ provided robust estimation of the scallop larvae distributions in the study area, as confirmed by model validation using independent data. These findings could contribute on the monitoring program in this region in order to distinguish the potential areas for an effective spat collection.
\end{abstract}

KEYWORDS: scallop larvae; spatial distributions; regression quantiles; GIS; remote sensing; Funka Bay

\section{INTRODUCTION}

The most important scallop species in Japan is Mizuhopecten yessoensis, also known as the giant ezo scallop ("hotate- gai" in Japanese). This is a cold water species living in the northern areas of Honshu Island, Hokkaido and the south of Okhotsk Sea, where the main cultivation areas are located (Kafuku \& Ikenoue,
1983). Scallop aquaculture plays an important role in economic and social welfare of the coastal communities and supports coastal communities with an annual increase of economic activity in shellfish productions. To achieve and sustain this level of harvest, the industry evolved from traditional wild fisheries to one based on cultivation. Indeed, the fishery is based entirely on intensive and

\# Corresponding author. Center for Aquaculture Research and Development, Jl. Ragunan 20, Pasar Minggu, Jakarta Selatan 12540, Indonesia. Tel.: + 62217805052 Email: radiarta@yahoo.com 
directed effort to collect wild scallop spat and then grow the spat to marketable size using several culture techniques (Uki, 2006).

As a part of the development of scallop cultivation in Japan, larvae collection and propagation are becoming an important factor. To support this cultivation industry, an extensive program for monitoring natural larvae abundances and spat collections has been carried out, for example in Mutsu Bay (Ventilla, 1982). This program enables culturists and researchers to investigate the scallop resources and distributions. Although monitoring program has been conducted, modeling of species distribution is becoming an important tool for conservation, resources management and understanding the effects of environmental changes (Austin, 2007; Vaz et al., 2008). Models can be constructed through an understanding of the habitat requirement and the association with ecological processes of the species, either direct or indirect factors.

With respect to modeling species distribution, Guisan \& Zimmermann (2000) and Austin (2007) have described and compared the methods for modeling species environmental niche or geographical distribution, whether plants or animals. General Linear Model (GLM) and Generalized Additive Modeling (GAM) were commonly a used method for species distribution modeling which were based on central tendency (mean or median). Although they provided valuable insights, these do not recognize the need to define the type of functional response based on ecological theory (Cade \& Noon, 2003; Austin, 2007). In order to reflect the ecological aspect of the limiting factors on species distribution, this study used Regression Quantile (RQ). The statistical concepts behind $\mathrm{RQ}$ have been well described (Koenker \& Hallock, 2001; Yu et al., 2003). RQ can be used to model limiting relations for ecological factors by estimating change near the upper limit of data distributions (Cade et al., 1999; Cade \& Noon, 2003). Recently, the applications of RQ on ecological studies have increased as a way of predicting a more complete range of species' responses to environment conditions (Cade \& Guo, 2000; McClain \& Rex, 2001; Dunham et al., 2002; Eastwood et al., 2003; McClain \& Crouse, 2006; Vaz et al., 2008).

Geographic Information System (GIS) and Remote Sensing (RS) are increasingly used for mapping spatial aspect of the development and resources management. Both GIS and RS technology are also used to define geographic framework, specify environmental constraints and identify resources limitation (Stead et al. 2002). Commonly, RS has become an important source of data used in GIS analysis. By using this technology, it can reduce the amount of field sampling and increase the spatial and temporal coverage of estimations. A combination of this technology would be a cost- effective and valuable tool for mapping, spatial planning and managing natural resources. Spatial predictive modeling (combined GIS based-models and empirical technique) are now routinely developed to study spatial and temporal species distributions and their habitat (Eastwood et al., 2003; Eastwood \& Meaden, 2004; Vaz et al., 2008; Bekkby et al., 2008). In the present study, an integration of RS, RQ and GIS were used to construct a model for providing estimation on the scallop larvae distributions. The RQ model was constructed based on estimated of the limiting effects imposed by a number of key environmental factors.

\section{METHODOLOGY}

\section{Study Area}

Funka Bay was the area chosen to develop the model (Figure 1). It lies between $42^{\circ} 00^{\prime}$ $42^{\circ} 35^{\prime}$ North and $140^{\circ} 18^{\prime}-141^{\circ} 00^{\prime}$ East, with a mean and maximum depth of $38 \mathrm{~m}$ and $107 \mathrm{~m}$, respectively. The bay has a $2,315 \mathrm{~km}^{2}$ surface area, and a $195 \mathrm{~km}$ coastline, and is connected to the northwest Pacific Ocean through a 30 $\mathrm{km}$ wide shallow sill in the east part of the bay. Sea surface temperature in the bay varies from $<5^{\circ} \mathrm{C}$ in March to $>20^{\circ} \mathrm{C}$ in August- September (Radiarta \& Saitoh, 2008). Salinity is relatively stable, ranging from 31 to $34 \%$ Chlorophyll- a levels are very high during the spring bloom in March, but relatively low $\left(<1 \mathrm{mg} \mathrm{m}^{-3}\right)$ during summer (Radiarta \& Saitoh, 2008). Water in the bay is replaced twice a year by the inflow of Tsuguru warm water from autumn to winter and Oyashio water (a subartic oceanic water mass) from spring to summer (Ohtani, 1971; Ohtani \& Kido, 1980). The unique of hydrographic and current systems around the bay provide a favorable environmental condition for marine aquaculture development. Scallop and kelp are widely cultivated by individuals, companies and fishermen associations. The bay is also a walleye pollock nursery ground (Honda et al., 2004). 
The use of remote sensing, regression quantiles ... (I Nyoman Radiarta)

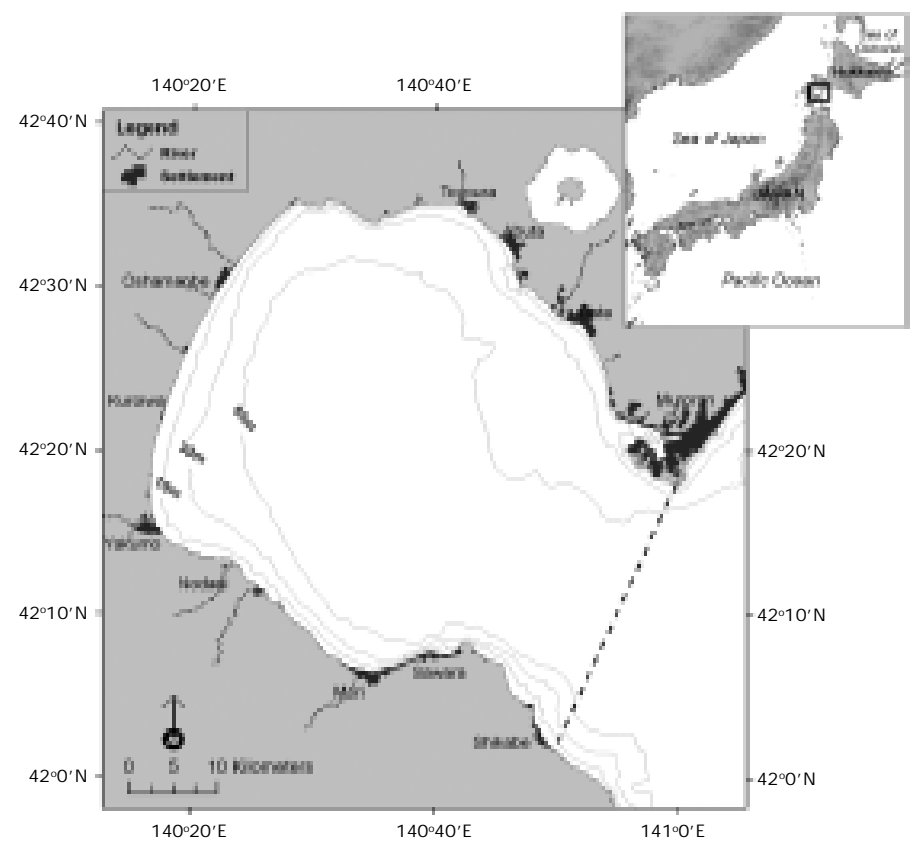

Figure 1. The study area, Funka Bay, southwestern Hokkaido, Japan and major depth0contours. Dashed bold line indicates border of the study area

\section{Scallop Larvae and Environmental Data}

The period of larvae collection in Funka Bay usually coincides with late spring to early summer (May to July; Ito, 1991). Data on scallop larvae (digital maps) in this study were obtained from Hokkaido Hakodate Fisheries Experimental Station through its website (http:// www.fishexp.pref.hokkaido.jp/exp/hakodate). These data were collected weekly during cruise of the R/ V Kinsei Maru from April to July 2003. The methodology used to collect and analyze the larvae is described in detail by Baba et al. (2009). In brief, the larvae were collected using a plankton net (300 mm diameter; NXX-13,95 $\mu \mathrm{m}$ mesh) hauled vertically from 15 $\mathrm{m}$ depth to the surface. The filtration rate of the plankton net was considered to be $100 \%$ The planktonic larvae were counted under a profile projector, and then identified. The density of larvae was calculated as number of larvae per ton seawater. Data of scallop larvae were imported into GIS as a vector point data through digitizing process. To standardize the analysis or mapping on this point data, these data were counted for an area of $1 \times 1 \mathrm{~km}^{2}$, and all data then combined into monthly based (Table 1; Figure 2).
Three environmental parameters which have high influence on scallop growth, such as sea surface temperature (SST), chlorophylla (chl-a) and water depth, were chosen (MacDonald \& Thompson, 1985; Emerson et al., 1994; Grant, 1996; Bacher et al., 2003). These parameters were extracted from several sources of data (multi sensor remotely sensed data and a hydrographic chart). SST data were derived from MODIS (Moderate Resolution Imaging Spectroradiometer)- Aqua sensor as level- 2 data with $1 \mathrm{~km}$ resolution from the Distribution Active Archive Centre Goddard Space Flight Centre National Aeronautic and Space Administration (DAAC/ GSFC/ NASA). Daily images with good coverage were collected from April to July 2003. Monthly composed SST images were computed by averaging all available images in each month. Monthly SST values were then extracted based on larvae sampling stations.

Chl- a data were derived from SeaWiFS (Seaviewing Wide Field- of- view Sensor) as level- 2 data with $1 \mathrm{~km}$ resolution from DAAC/GSFC/ NASA. The chl- a images were processed using the SeaWiFS chlorophyll algorithm Ocean Color 4 version 4 (OC4v4) (O'Reilly et al., 1998). Daily images with good coverage were selected for 
Indonesian Aquaculture Journal Vol.6 No.2, 2011

Table 1. Number of observations ( $n$ ) available for model estimation and validation

\begin{tabular}{lccc}
\hline \multirow{2}{*}{ Month } & $\mathbf{n}$ & \multicolumn{2}{c}{$\mathbf{n}$ for model } \\
\cline { 3 - 4 } & & Estimation & Validation \\
\hline April 2003 & 19 & 13 & 6 \\
Mei 2003 & 156 & 141 & 15 \\
Juni 2003 & 140 & 130 & 10 \\
Juli 2003 & 10 & 8 & 2 \\
\hline \multicolumn{1}{c}{ Total } & $\mathbf{3 2 5}$ & $\mathbf{2 9 2}$ & $\mathbf{3 3}$ \\
\hline
\end{tabular}
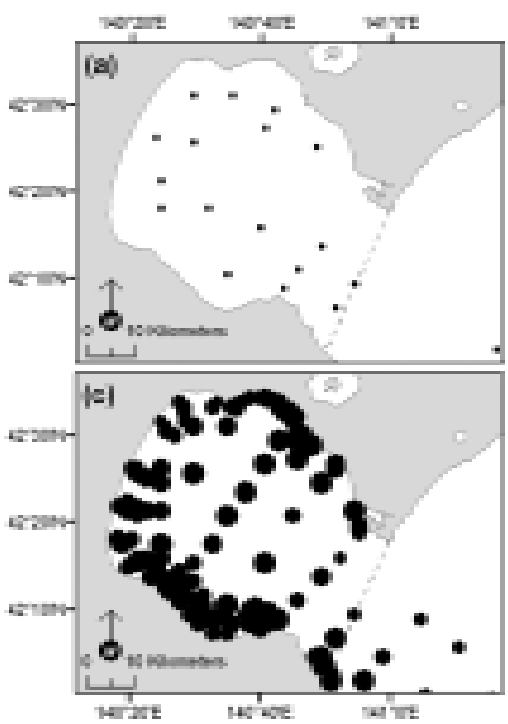
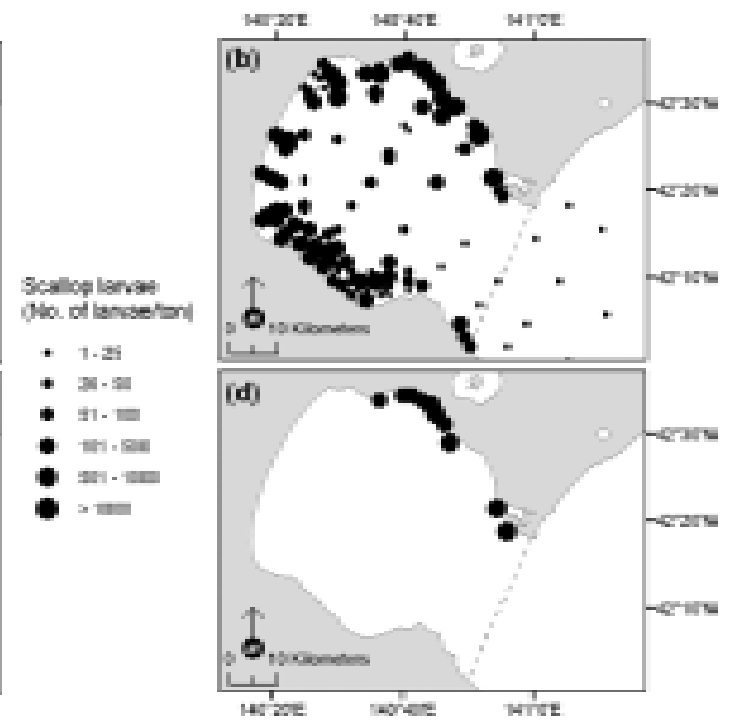

Figure 2. Distribution of Japanese scallops larvae (Number of larvae per ton seawater) in Funka Bay: (a) April 2003, (b) May 2003, (c) June 2003 and (d) July 2003). Dashed line indicates the extent of the study area

the period of April to July 2003. Monthly composed chl- a images were computed by averaging all available images in each month. In the case of images covered by cloud, these were replaced using the distance weight interpolation (a raster based interpolation). Monthly chl- a values were then extracted based on larvae sampling stations.

A hydrographic chart from the survey map of the Japan Hydrographic Department $(1: 150,000)$ was scanned on a Canon (CanoScan FB62OU) scanner with 200 dpi resolution, edited in Adobe Photoshop version 5.5 (a raster format image- editing software), and imported into GISsoftware. The image was digi- tized using on-screen digitizing to produce bathymetric feature (point data). The Triangulated Irregular Network (TIN) technique was used to create a raster bathymetric map. Water depths for the larvae sampling stations were then extracted.

\section{Regression Quantile Model}

The ecological applications of RQ have been used only recently (MacClain \& Rex, 2001; Eastwood et al., 2003; Cade \& Noon, 2003; Vaz et al., 2008). Cade \& Noon (2003) describes the RQ for ecologists and presents many new possibilities for the statistical analysis and interpretation of ecological data. De- 
tails of the statistical theory behind RQ have been reported elsewhere (e.g., Koenker \& Hallock, 2001; Yu et al., 2003). Briefly, RQs are the linear model equivalent to one-sample quantiles in which they allow data distribution to be split into quantile classes range from $0-1$ (e.g., $0.5=50^{\text {th }} \mathrm{RQ}$ ). One- sample quantile is extended to regression by minimizing a function of absolute error loss. The $50^{\text {th }} \mathrm{RQ}$ is equivalent to Least Absolute Deviation (LAD) where $50 \%$ of the observation are less than and $50 \%$ greater than the estimate. LAD regression estimates the conditional medians in a linear model, and is opposed to Ordinary Least Squares (OLS) which estimates conditional means. Any quantile can be estimated conditionally on the linear model $y=\beta X+v(X)_{\varepsilon}$, where $\mathrm{y}$ is a vector of $\mathrm{n} \times 1$ dependent responses (e.g., scallop larvae), $\beta$ is a vector of $p \times 1$ unknown regression parameters, $X$ is a matrix of $\mathrm{n} \times \mathrm{p}$ predictors (first column consists of ones), $v()>$.0 is some known function, and $\varepsilon$ is a vector of $n \times 1$ vector random error that are independent and identically distributed (Cade et al., 1999). To estimate RQ parameters, the BLOSSOM statistical software program was used (Cade \& Richard, 2005; available at: http:/ / www.fort.usgs.gov/ products/ software/ blossom/). Levels of significance and Confidence Intervals $(\mathrm{Cl})$ were also evaluated within quantreg package of $\mathrm{R}$ using rank-score test statistic which is appropriated for models associated with a heterogeneous error distribution.

The models were estimated through all levels of RQ from the lower to higher quantiles $\left(5^{\text {th }}\right.$ to $95^{\text {th }}$ quantiles) in order to provide distribution-free prediction interval for a single new sample location. To reduce heteroscedasticity in data and to limit the effect of heterogeneous error distribution model (Cade \& Richard, 2005), parameters estimation were based on $\ln (y+1)$ transformed larvae density (as the dependent variable). Cade et al. (2005) pointed out that weighted quantile regression may be more appropriate for non- homogeneous data, but is computationally difficult to implement. Instead, we used data transformation to reduce the heteroscedasticity in our data. The RQ models were therefore constructed to transformed data and subsequently transformed back into the original scale. All environmental parameters, i.e. water depth, chl- a and SST, were included in the initial analysis as independent variables. The significance of each parameter was evaluated over the lower and higher quantiles. The parameter indicating no significance, taken over the range of quantiles, was then removed. If in case over more than one quantiles are significant $(P<0.05)$, the highest quantile was chosen as the model to represent larvae density imposed by the environment. In the analysis, we assumed that the effects of the parameters are multiplicative instead of additive. Indeed, a multiplicative model is more relevant than an additive model with regard of limiting factors.

To compare the models and assess whether the selection procedure resulted in an appropriate model, the Akaike's Information Criterion (AIC) values were calculated and compared to a number of alternative RQ models. The AIC for RQ models was calculated as (Hurvich \& Tsai, 1990; Cade et al., 2005):

$$
\operatorname{AIC}_{c}(\tau)=2 n \times \ln (\operatorname{SAF}(\tau) / n)+2 p(n /(n-p-1))
$$

where $\mathrm{n}$ is the number of observations and $\operatorname{SAF}(\tau)$ is the weighted sum of absolute deviations minimized in estimating the $\tau$ th RQ with p parameters. Absolute differences $\left(\triangle \mathrm{AIC}_{\mathrm{C}}(\tau)\right)$ between $\operatorname{AIC}_{c}(\tau)$ value for the simple model $\left(\beta_{0}\right)$ and for the complex models were computed. The model that has the minimum is usually indicated as the best model.

Coefficient of determination $\left(R^{1}\right)$ was also calculated to measure of goodness- of- fit of RQ models. Note we refer $R^{1}$ and not $R^{2}$ (least squares equivalent), because $R Q$ minimize absolute not squared deviation. The $\mathrm{R}^{1}$ was calculated as (Cade \& Richard, 2005):

$$
\mathrm{R}^{1}=1 \text { - (SAF / SAR) }
$$

where SAF and SAR are the weighted sum of absolute deviations for full $\left(\beta_{0}+\beta_{1}+\beta_{2}+\beta_{3}\right)$ and reduced $\left(\beta_{0}\right)$ parameters models, respectively.

\section{Constructing the Spatial Predicted Model}

A prediction spatial distribution model of larvae density for Japanese scallop in Funka Bay was developed by recoding the environmental parameter maps using the predicted larvae density obtained from the final RQ model. The predicted map was created in ArcGIS ®v.9.2 (The Environmental System Research Institute, USA). All spatial data used in the GIS models were built on a WGS 84 UTM zone 54 North coordinate system. 


\section{Model Validation}

Model validation was based on direct comparison between predicted and observed scallop larvae. From the total available larvae survey stations, 33 stations were randomly selected and further used as validation data set (Table 1). To make a comparison, environmental values (such as water depth, chl- a and SST) associated with larvae survey stations were calculated using the RQ model to obtain a set of predicted larvae density. The correct validation of the model for estimating limiting effects was assessed by proportion of observed values in validation data set that fall below or located upper those predicted (Eastwood et al., 2003; Vaz et al., 2008). For example, if the habitat model was developed from a $95^{\text {th }} \mathrm{RQ}$, then for the test to be successful, at least $95 \%$ of all observed values should fall below those predicted. On the other hand, if $5^{\text {th }} \mathrm{RQ}$, then at least $95 \%$ of all observed values should be located upper than those predicted.

The values predicted by the RQ model are lower or higher than most of the observed values, therefore statistical correlation of the Spearman's rank correlation coefficient $\left(r_{s}\right)$ was preferred as it does not assume a linear relationship between variables (Vaz et al., 2008). The successful test would be expected by a positive and significant correlation between observed and predicted larvae density.

\section{RESULTS AND DISCUSSIONS}

A summary of the results used to develop the RQ model is given in Table 2 . Within each month mean larvae densities were generally increased from April to June, with the highest in June and then decreased in July. The mean SST was gradually increased from $3.44^{\circ} \mathrm{C}$ in
April to $13.10^{\circ} \mathrm{C}$ in July, whilst chlorophyll was highest in May. Figure 3 illustrates the environmental preferences observed for Japanese scallop larvae. Larvae densities were generally highest within water of approximately less than $50 \mathrm{~m}$ depth, at chlorophyll greater than $0.4 \mathrm{mg} \mathrm{m}^{-3}$ and at SST between $7-13^{\circ} \mathrm{C}$. Regression coefficients of all environmental parameters are shown in Figure 4. Depth regression coefficient was found to be overlapped with zero in a number of cases, i.e. quantiles $<30^{\text {th }}$ and $>85^{\text {th }}$, whereas for chl- a regression coefficient, quantiles were found to be overlapped with zero at all range of quantiles. Only SST regression coefficients were found to be nonzero at all the RQ. This initial analysis highlighted how the value of the regression estimates may vary over the range of all quantiles (Figures 4 a- d).

\section{Model Specification and Prediction}

As depth and chl- a were not retained as an explanatory parameters within RQ model, only SST was considered in the model. The model of best fit arrived by using only SST parameters as independent variable, and it was based on In transformed larvae density as dependent variable. The $95^{\text {th }}$ quantile was the highest quantile and indicated significant for this model $(P<0.001)$. This quantile also achieved the best model which was indicated by the lowest value (Table 3). Estimates for the $95^{\text {th }} \mathrm{RQ}$ were $\mathrm{b}_{0}$ (intercept) $=3.436(90 \% \mathrm{Cl}=1.788-5.012)$ and $b_{1}=0.343(90 \% \mathrm{Cl}=0.209-0.515)$. These estimate parameters for the RQ model were chosen to represent the limit of scallop larvae distributions in Funka Bay, which was. The model was associated with an $\mathrm{R}^{1}$ of $15.96 \%$ (Table 3 ). The $\mathrm{R}^{1}$ value reflects the amount of data scatter around the RQ line.

Table 2. Mean number (standard error) of scallop larvae from April to July 2003, and associated environmental parameters. The location of scallop larvae distribution is shown in Figure 2

\begin{tabular}{cccccc}
\hline Month & $\mathbf{n}$ & $\begin{array}{c}\text { Larvae } \\
\text { (no. of larvae/ton) }\end{array}$ & $\begin{array}{c}\text { Depth } \\
\mathbf{( m )}\end{array}$ & $\begin{array}{c}\text { Chl-a } \\
\left(\mathbf{m g ~ m}^{-3} \mathbf{)}\right.\end{array}$ & $\begin{array}{c}\text { SST } \\
\left({ }^{\circ} \mathbf{C}\right)\end{array}$ \\
\hline April & 19 & $4(0.83)$ & $73.88(4.41)$ & $0.86(0.07)$ & $3.44(0.17)$ \\
May & 156 & $146(18.59)$ & $43.38(2.07)$ & $1.46(0.05)$ & $8.22(0.08)$ \\
June & 140 & $651(61.39)$ & $44.05(2.36)$ & $1.02(0.11)$ & $12.00(0.11)$ \\
July & 10 & $483(82.88)$ & $24.22(2.96)$ & $0.34(0.01)$ & $13.10(0.33)$ \\
\hline
\end{tabular}



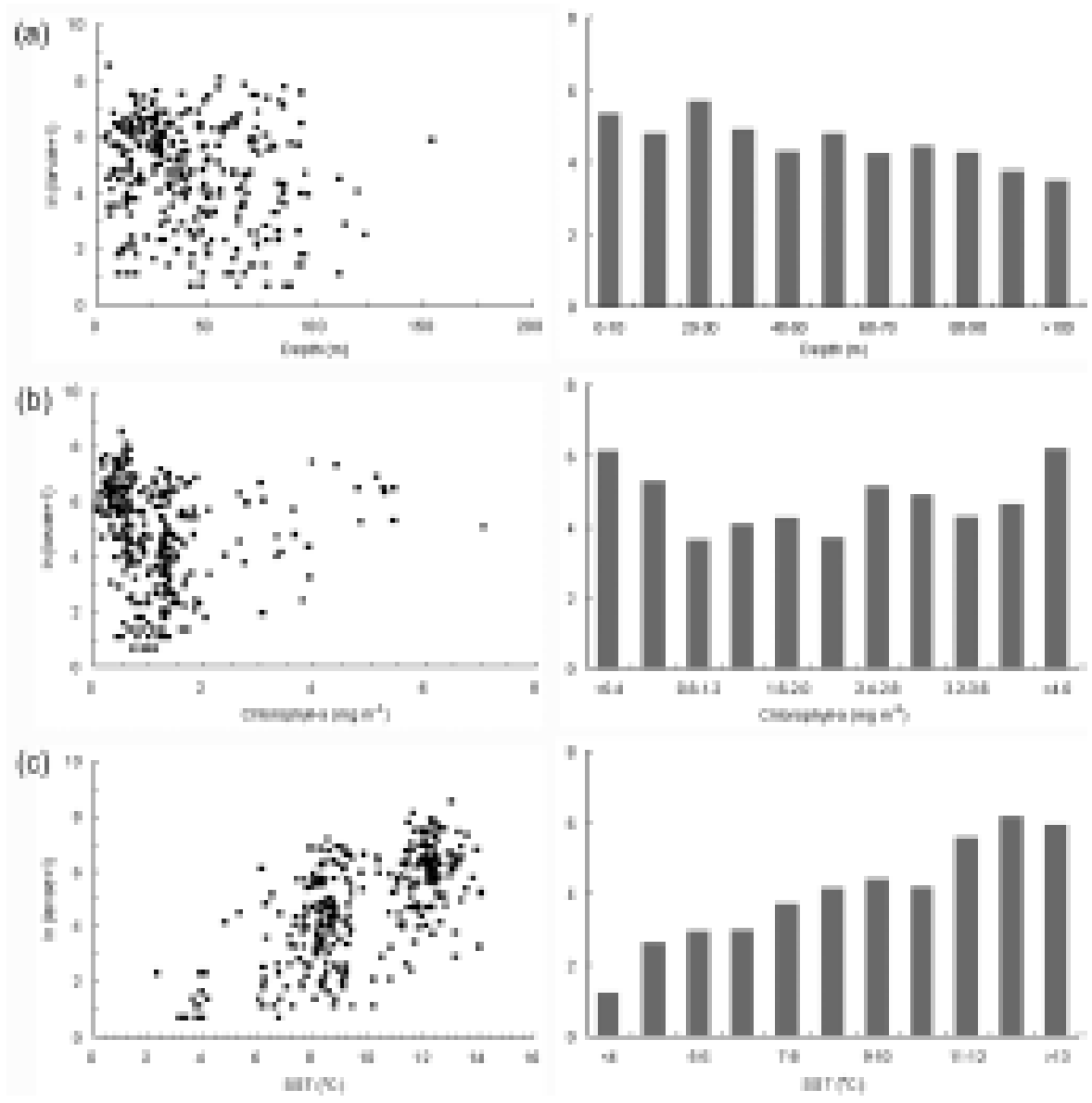

Figure 3. Scatterplots (left) and histogram of mean larvae concentration (In (larvae+1)) (right) of observed scallop larvae concentration as a function of environmental parameters: (a) depth (m), (b) chlorophyll- a $\left(\mathrm{mg} \mathrm{m}^{-3}\right)$ and (c) SST $\left({ }^{\circ} \mathrm{C}\right)$

The final map of predicted larvae densities for Japanese scallop obtained from the $95^{\text {th }} \mathrm{RQ}$ model in Funka Bay is shown in Figure 5a. In addition, we also mapped the surface area based on the lower $\left(5^{\text {th }}\right)$ RQ model (Figure $\left.5 b\right)$, in order to assess potential differences between models based on the upper and lower estimates. The models appeared visually similar, in which for all cases the highest larvae densities were predicted in a relatively broad distribution along the shallow water regions (Toyoura and Sawara to Yakumo), and the deeper water areas (center of the bay). The models based on upper quantile clearly predict a higher density of scallop larvae compared to the lower quantile models (Table 4). The upper model predicted larvae density of
650- 850 number of larvae per ton was found to be dominant and occupied more than half of the study area ( $53 \%$ ). Approximately $42 \%$ of the study area had predicted larvae density of $>850$ number of larvae per ton. Given the ideal environmental condition, predictions from upper RQ model $\left(95^{\text {th }}\right)$ tends to describe potential patterns of species distributions, which might overestimate species density and distribution to illustrate the species maximum abundance.

\section{Quantile Model Validation}

In the model validation, 33 independent data were selected randomly in order to avoid the special correlation on the dataset. The result shows that direct comparison between 
Indonesian Aquaculture Journal Vol.6 No.2, 2011
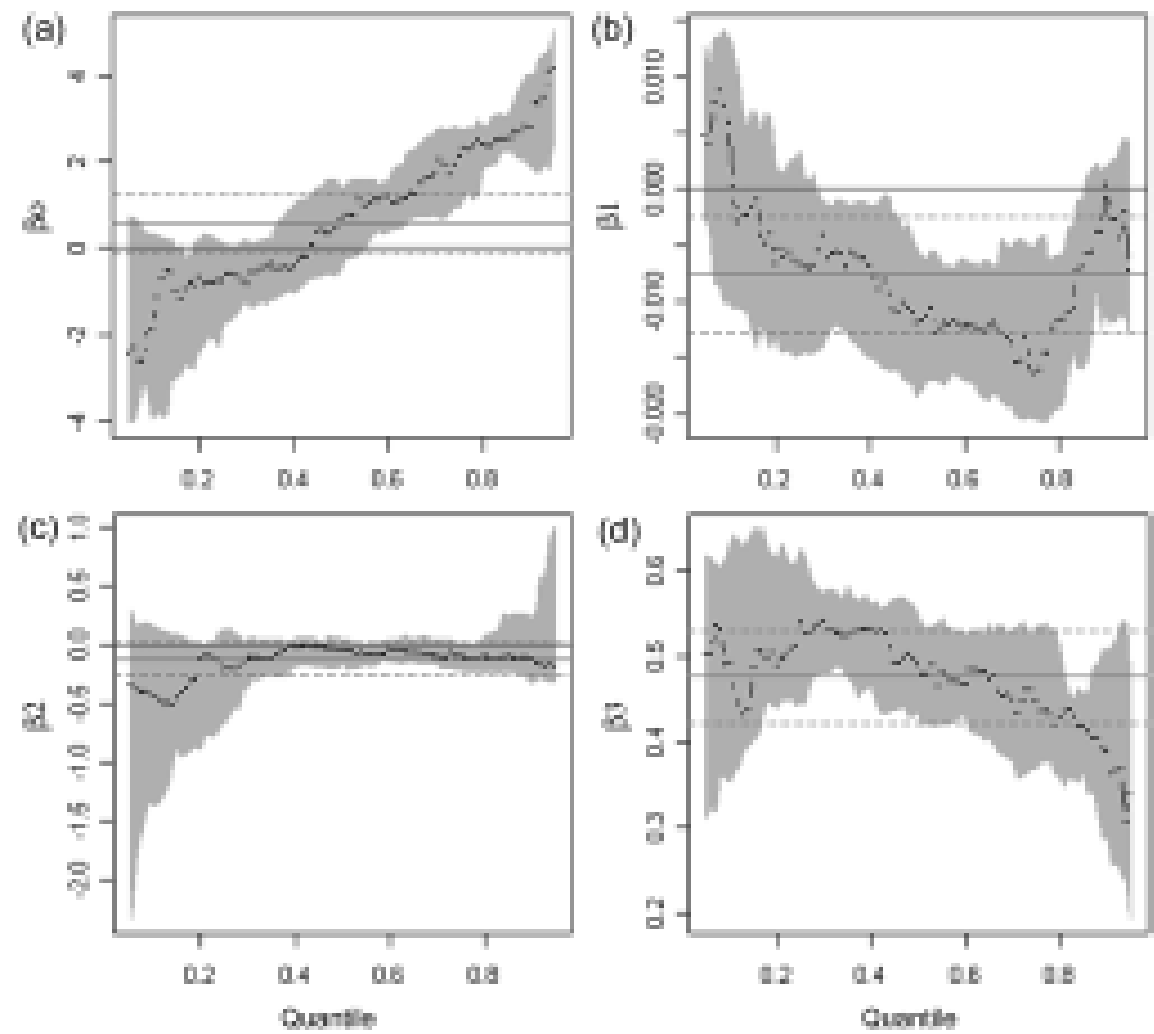

Figure 4. Parameter estimates for the regression quantile models $\left[\ln (y+1)=\beta_{0}+\beta_{1} X_{1}\right.$ $+\beta_{2} X_{2}+\beta_{3} X_{3}+\varepsilon$ ] over the range 0.05- 0.95 (dotted lines): (a) intercept, (b) depth, (c) chlorophyll- $a$ and (d) SST. The shaded gray area depicts $90 \%$ point wise confidence band for the quantile regression estimates. Gray line in each figure indicates the ordinary least squares estimate of the conditional mean effect. The two dashed lines represent conventional $90 \%$ confident intervals for the least squares estimate

Table 3. Estimates of $b_{0}$ and $b_{1}$, and their Confidence Intervals $(\mathrm{Cl})$ from rank score tests, together with $\mathrm{P}$ - value, SAF, $\mathrm{R}^{1}$ and $\triangle \mathrm{AIC}_{\mathrm{c}}(\tau)$ for five selected regression quantiles $\left(5^{\mathrm{th}}\right.$, $10^{\text {th }}, 25^{\text {th }}, 50^{\text {th }}, 75^{\text {th }}$ and $95^{\text {th }}$ )

\begin{tabular}{|c|c|c|c|c|c|c|c|c|}
\hline \multirow{2}{*}{$\begin{array}{c}\text { Quantile } \\
(\tau)\end{array}$} & \multirow{2}{*}{$\begin{array}{c}\text { Intercept } \\
\left(\beta_{0}\right)\end{array}$} & \multirow{2}{*}{$\begin{array}{l}\text { SST } \\
\left(\beta_{1}\right)\end{array}$} & \multicolumn{2}{|c|}{$\mathbf{C l}$} & \multirow{2}{*}{ Pvalue } & \multirow{2}{*}{ SAF } & \multirow{2}{*}{$\begin{array}{l}\text { R1 } \\
\text { (\%) }\end{array}$} & \multirow{2}{*}{$\Delta \mathbf{A} \mathbf{C}_{\mathbf{c}}(\tau)$} \\
\hline & & & $\left(\beta_{0}\right)$ & $\left(\beta_{1}\right)$ & & & & \\
\hline 5 & -1.592 & 0.373 & $-3.838-(-0.54)$ & $0.248-0.605$ & $6.18 \mathrm{E}-11$ & 43.43 & 21.61 & 142.19 \\
\hline 10 & -2.005 & 0.489 & $-3.434-(-0.794)$ & $0.341-0.629$ & 4.99E-15 & 75.9 & 25.11 & 168.83 \\
\hline 25 & -1.243 & 0.518 & $-2.487-(-0.797)$ & $0.480-0.621$ & $1.52 \mathrm{E}-23$ & 135.34 & 29.81 & 206.73 \\
\hline 50 & -0.496 & 0.535 & $-1.188-0.364$ & $0.459-0.601$ & $1.27 \mathrm{E}-12$ & 161.59 & 28.81 & 198.43 \\
\hline 75 & 1.277 & 0.444 & $0.178-2.946$ & $0.296-0.556$ & 1.27E-12 & 125.87 & 19.18 & 124.36 \\
\hline 95 & 3.436 & 0.343 & $1.789-5.012$ & $0.209-0.515$ & $1.40 \mathrm{E}-04$ & 36.25 & 15.96 & 101.57 \\
\hline
\end{tabular}

$\mathrm{SAF}$ is the weighted sum of absolute deviations minimized parameters models; $\mathrm{R}^{1}$ is coefficient determination; and $\triangle \mathrm{AIC}_{\mathrm{c}}(\tau)$ is absolute difference between the simple (null) model and selected alternative model AIC. 
The use of remote sensing, regression quantiles ... (I Nyoman Radiarta)
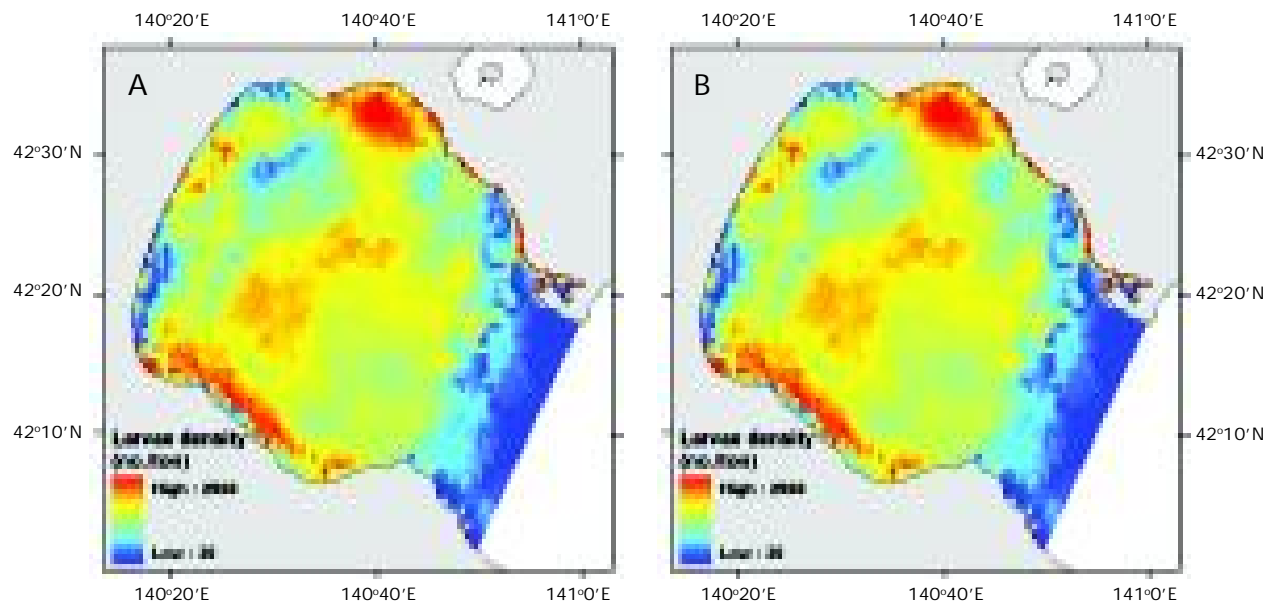

Figure 5. Predicted scallop larvae (number of larvae per ton sea water) in Funka Bay given by (a) the upper $\left(95^{\text {th }}\right)$ and $(b)$ lower $\left(5^{\text {th }}\right)$ regression quantile models

Table 4. Proportion of the total mapped surface area (\% of larvae density, for maps based on the $95^{\text {th }}$ and $5^{\text {th }}$ regression quantile models in Funka Bay, Hokkaido, Japan

\begin{tabular}{lccccc}
\hline \multicolumn{1}{c}{ Models } & \multicolumn{5}{c}{ Larvae density/ mapped surface area } \\
\hline$\underline{95}^{\text {th }} \stackrel{\text { regression quantile }}{\text { Larvae density (no./ ton) }}$ & $<250$ & $250-450$ & $450-650$ & $650-850$ & $>850$ \\
Mapped surface area (\%) & 0.1 & 0.2 & 5.2 & 52.5 & 42 \\
\hline$\underline{5}^{\text {th }}$ regression quantile & $>4$ & $4-5$ & $5-6$ & $6-7$ & $>7$ \\
Larvae density (no./ ton) & 3 & 8 & 22 & 54 & 13 \\
Mapped surface area (\%) & 3 & & & & \\
\hline
\end{tabular}

predicted and observed larvae densities models were observed to pass the correct classification test successfully, and provided a good estimation (Table 5; Figure 6). Based on the four selected quantiles, statistical correlations between predicted and observed larvae densities were positively correlated with Spearman's rank correlation $\left(r_{s}\right)$ of $0.65(\mathrm{P}<$ $0.001, n=33$; Table 5). Proportion of observed larvae densities based on $5^{\text {th }}$ and $95^{\text {th }}$ quantiles were about $100 \%$ higher and about $97 \%$ less than those predicted, respectively. Meanwhile, proportion for the $25^{\text {th }}$ and $75^{\text {th }}$ quantile were about $81.82 \%$ either less or higher than those predicted, respectively.

\section{Discussions}

Scallop is one of the main important cultivated shellfish in Funka Bay, Hokkaido. The future development and sustainability of scal- lop aquaculture in this bay, would depends on a number of factors, including environmental condition, availability of larvae supply (spat collections), spatial and temporal scale of the culture and management strategies. Data on scallop larvae have been accumulated for a long time by many investigators, since the information about spawning and the occurrence of planktonic larvae are required for effective spat collections. Spat collection is one of the success factors of scallop aquaculture in the bay. In some areas where scallops are cultivated (i.e., Mutsu Bay, Japan; 410.' N, $\left.140^{\circ} 59^{\prime} \mathrm{E}\right)$, a monitoring program for scallop larvae and the environmental parameters has been conducted, with a variety of forecasting techniques including gonad index, cumulative water temperature and size composition of the swimming larvae (Ventilla, 1982; Lovatelli, 1988). This monitoring program has three main 
Indonesian Aquaculture Journal Vol.6 No.2, 2011

Table 5. Data proportion, location and statistical correlation between predicted and observed larvae densities

\begin{tabular}{cccc}
\hline $\begin{array}{c}\text { Quantile } \\
(\tau)\end{array}$ & $\begin{array}{c}\text { Data } \\
\text { proportion } \\
(\mathbf{\%})\end{array}$ & $\begin{array}{c}\text { Location of new } \\
\text { observations }\end{array}$ & $\begin{array}{c}\text { Spearman's rank } \\
\text { correlation } \\
\left(\mathbf{r}_{\mathbf{s}} ; \mathbf{P}<\mathbf{0 . 0 0 1 )}\right.\end{array}$ \\
\hline 5 & 100 & Upper predicted quantile & 0.65 \\
25 & 81.82 & Upper predicted quantile & 0.65 \\
75 & 81.82 & Below predicted quantile & 0.65 \\
95 & 96.97 & Below predicted quantile & 0.65 \\
\hline
\end{tabular}

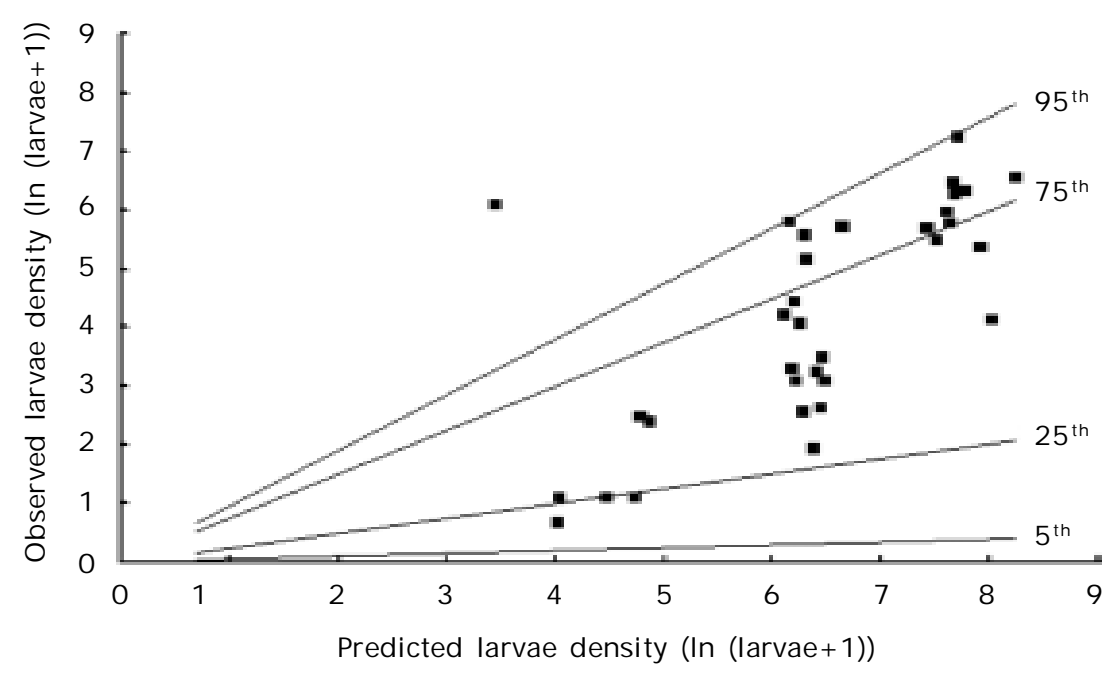

Figure 6. Plot of transformed observed scallop larvae concentrations against those predicted by the $95^{\text {th }}$ regression quantile model. Dashed lines indicate regression lines for $5^{\text {th }}, 25^{\text {th }}, 75^{\text {th }}$ and $95^{\text {th }}$ quantiles

objectives which are prediction of larvae settlement time, larvae density, and monitoring of the larvae distribution. Through this program, the best location for settling the collectors could be determined. In site selection decision, the larvae should be available within the vicinity of the selected sites (Lovatelli, 1988; Hardy, 1991).

In this study, remotely sensed data were used extensively for extracting environmental parameters. Three environmental parameters (water depth, chl- a and SST) were selected and used for modeling larvae distributions. These parameters were found to be related to the distribution of scallop larvae from April to July, 2003 (Figure 3). Several studies have shown the influences of these parameters to the larvae distribution either on shellfishes (Tremblay \& Sinclair, 1990; McClain $\&$ Rex, 2001; McClain \& Crouse, 2006) or on fishes (Dunham et al., 2002; Eastwood et al., 2003; Vaz et al., 2008). A high density of scallop larvae was observed within shallow water regions (approximately less than $50 \mathrm{~m}$ depth; Figure 3a). This condition was similar with those reported previously by Ventilla (1982), where scallop larvae were concentrated between 5$15 \mathrm{~m}$ with a slight migration downward during the day and upward at night. Scallop relies on phytoplankton and suspended detrital matter as food. Phytoplankton biomass is responsible for supplying natural food, and chl- a was used as an indicator of this biomass. Other information on specific food items utilized by scallops in their natural habitat is limited. However, in hatchery industry, typical phytoplankton cells were used for feeding scallop larvae in- 
cluding Monochrysis lutheri, Chaetoceros calcitrans, Isochrysis galbana, Phaeodactylum tricornutum, Dunaliella tertiolecta, Rhodomonas sp. and Gymnodium spendens (Lovatelli, 1987). The variability of SST influences the scallop larvae spawning season (Table 2). The spawning of this species usually occurs in March and April when the water temperature rises from 5 to $10^{\circ} \mathrm{C}$ (Kafuku \& Ikenoue, 1983; Ito, 1991). The influence of water temperature was also reported by Eastwood et al. (2001) when they studied the spatial variation in spawning habitat suitability for the sole (Solea solea) within the eastern English Channel and southern North Sea.

In our model, scallop larvae distribution was constructed based only on SST (Table 3; Figure 5). Water depth and chl- a are also important factors affecting the scallop growth/ distribution (Grant, 1996; Bacher et al., 2003, Baba et al., 2009), however, these parameters indicated no significant, and in some cases their $\mathrm{Cl}$ were overlapped with zero (Figure 4). Furthermore, besides the environmental parameters that we considered, other factors might influence the scallop larvae distribution, such as wind condition and water current. Water current is also thought to contribute towards larvae transport and movement either shellfish Iarvae (Peña et al., 1996; Maeno et al., 2002) or fish larvae (Shimizu \& Isoda, 1997; Honda et al., 2004). Honda et al. (2004) suggested that coastal current plays an important role in the movement of juvenile walleye pollock from the Funka Bay spawning ground to the Doto nursery ground along the Pacific Coast of Hokkaido. The occurrence of the anti cyclonic eddy in the center of Funka Bay and extended horizontally over the entire bay area during summer has influenced the transport and distribution of scallop larvae in the bay (Takahashi et al., 2004). Figure 7 shows an evidence of the development of the anti cyclonic eddy in the center of bay using the SST image on June 6, 2003. The present of the anti cyclonic eddy in the center of bay coincided with high larvae density (Figures 2c and 4). In addition, wind condition also influenced water circulation in Funka Bay (Inoue et al., 2000). A strong, seasonal southeasterly wind usually blows for a few days during the planktonic larvae phase (May) in Funka Bay (Baba et al., 2009). This event influences the densities of scallop larvae along the bay. In addition of scallop larvae, Shimizu

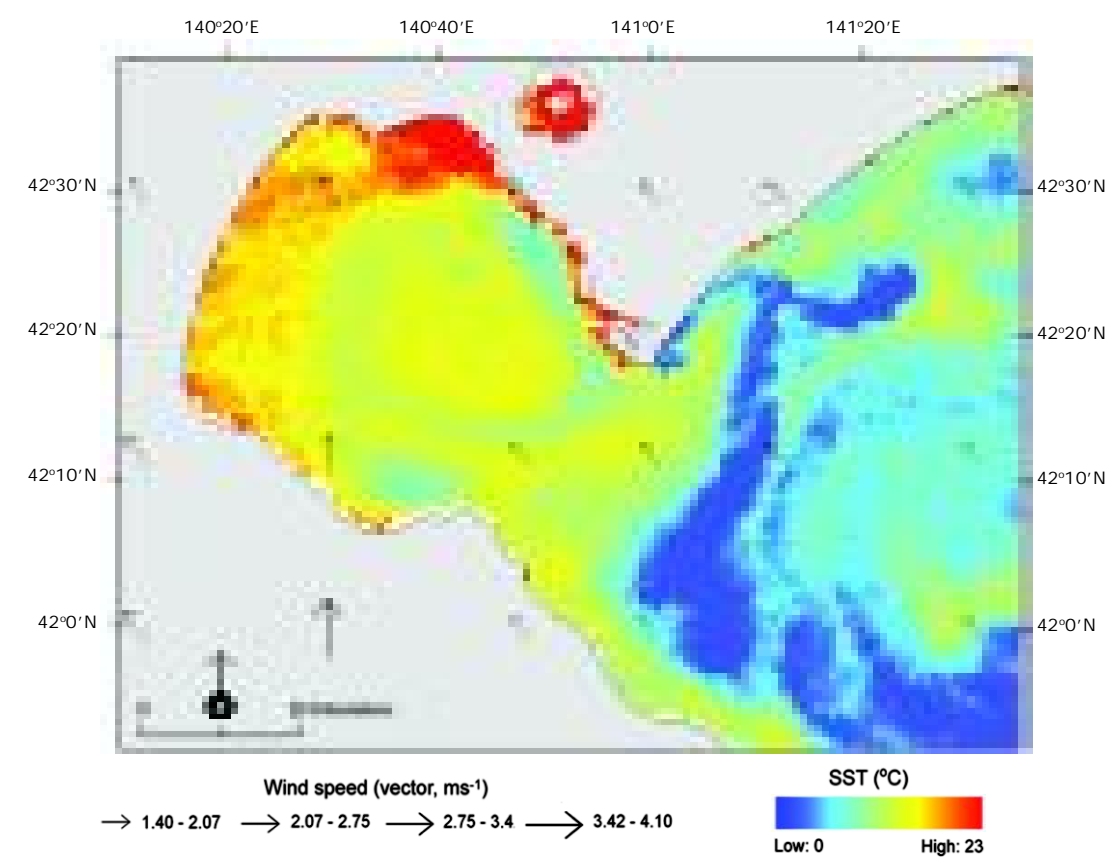

Figure 7. The influence of the anti cyclonic eddy on scallop larvae distributions in June 2003 indicated by SST $\left({ }^{\circ} \mathrm{C}\right)$ image on June 6,2003 , and overlaid with wind speed vector $\left(\mathrm{m} \mathrm{s}^{-1}\right)$ 
\& Isoda (1997) noted that the transport process of walleye pollock eggs in Funka Bay has also affected by the combination of the predominantly northwesterly winds and the bottom topography of the bay. Using winds data obtained from National Climatic Data Center through Live Access Server at NOMADS with $0.25^{\circ}$ spatial resolution (http:// nomads.ncdc.noaa.gov:8085/las/servlets/ dataset), high larvae density occurred in June (Table 2) and mostly distributed along the coast (Figure 2c) were observed during northwesterly wind direction (Figure 7). Winds forcing seem to influence the distribution of scallop larvae by affecting the water circulation (Takahashi et al., 2007) and productivity in the bay (Shimada et al., 2000).

RQ has several advantages for species distribution modeling. Since RQ was applied in ecology relatively recently (Cade \& Noon, 2003), many ecologists still remain unaware. By estimating the upper bounds of speciesenvironment relationship, these have enabled detection of the effect on limiting factors of species responses. Cade et al. (1999) suggested that an upper RQ provide an approximate which is more consistent with the ecological theory of limiting factors than by estimation through the center of data distributions. In this study, by modeling the upper bound $\left(95^{\text {th }}\right.$ quantile), the scallop larvae model has successfully estimated the limiting effects of environment on larvae density, and highlighted the importance of the environmental parameters. The highest larvae densities were found along the coastal areas (Toyoura and Sawara to Yakumo), and the deeper water areas (center of the bay) (Figure 4). A prediction map produce from the upper quantile model was intended to describe not only the actual pattern, but also the potential pattern of species distribution (Eastwood et al., 2003; Vaz et al., 2008). Potential distributions describe areas where the environmental conditions were suitable, as opposed with real distributions, which was the region of the potential distributions where the species actually occurs (Vaz et al., 2008).

The model performed relatively well under the validation test using 33 randomly0selected samples from four different months (April to July 2003). These validation data represented a snapshot of environmental condition at a certain time. Based on the selected quantile mod- els $\left(10^{\text {th }}, 25^{\text {th }}, 75^{\text {th }}\right.$ and $\left.95^{\text {th }}\right)$, the test has performed successfully, because most observed values fall below and located upper the predicted values (Eastwood et al., 2003; Figure $6)$. Furthermore, positive and significant correlation was achieved when testing using Spearman's rank correlation (Table 5). This correlation provided an assessment of general correlative trends.

\section{CONCLUSIONS}

This study has demonstrated the use of remotely sensed data, RQ and GIS approaches to obtain the spatial predictions and potential distributions of scallop larvae. The model estimated indicates consistency with ecological theory of limiting factors through relationship between species abundances and environmental variables. The model of scallop larvae distribution developed in this study was far from definitive, particularly the larvae distribution which was based on a single spawning season and limited environmental parameters. Annual variation of abundance scallop larvae could potentially lead to difference model output. Furthermore, environmental data used in this study (chl- a and SST) were extracted from remote sensing data which indicated surface value rather than bulk value. However, the model does represent a methodology to achieve more reliable prediction map of scallop larvae density from a difference source of data and limited number of environment parameters available. The modeling techniques presented here have practical and relevant benefits for resource management and habitat conservation. Based on the proportion total mapped areas, it indicated that Funka Bay has potential habitat for scallop larvae. Finally, the result from this model could assist fishermen (or FCAs) to distinguish the potential areas of scallop larvae in order to be used for an effective spat collection.

\section{ACKNOWLEDGEMENT}

I thank Hokkaido Hakodate Fisheries Experimental Station for providing scallop larvae distribution data. also thank the GSFC/DAAC of NASA for the production and distribution of SeaWiFS and MODIS data, NOAA/ NESDIS/ National Climatic Data Center (NCDC) for blended wind data. I am very grateful to Sei- Ichi Saitoh who contributed greatly to manuscript improvement. 
The use of remote sensing, regression quantiles ... (I Nyoman Radiarta)

\section{REFERENCES}

Austin, M.P. 2007. Species distribution models and ecological theory: a critical assessment and some possible new approaches. Ecol. Model., 200: 1- 19.

Baba, K., Sugawara, R., Nitta, H., Endou, K., \& Miyazono, A., 2009. Relationship between spat density, food availability, and growth of spawners in cultured Mizuhopecten yessoensis in Funka Bay: concurrence with El Nino Southern Oscillation. Ca. J. Fish. Aquat. Sci., 66: 6- 17.

Bacher, C., Grant, J., Hawkins, A.J.S., Fang, J., Zhu, M., \& Besnard, M. 2003. Modelling the effect of food depletion on scallop growth in Sungo Bay (China). Aquat. Living Resour., 16: 10- 24.

Bekkby, T., Rinde, E., Erikstad, L., Bakkestuen, V., Longva, O., Christensen, O., Isaus, M., \& Isachsen, P.E. 2008. Spatial probability modelling of eelgrass (Zoster a marina) distribution on the west coast of Norway. ICES J. Mar. Sci., 65: 1,093- 1,101.

Cade, B.S., Terrell, J.W., \& Schroeder, R.L. 1999. Estimating effects of limiting factors with regression quantiles. Ecology, 80: 311- 323.

Cade, B.S. \& Guo, Q. 2000. Estimating effects of constraints on plant performance with regression quantile. Oikos, 91: 245- 254.

Cade, B.S. \& Noon, B.R. 2003. A gentle introduction to quantile regression for ecologists. Front Ecol. Environ., 1: 412- 420.

Cade, B.S. \& Richards, J.D. 2005. User manual for blossom statistical software. Open file report 2005- 1353. U.S. Geological Survey, Reston, Virginia, $124 \mathrm{pp}$.

Cade, B.S., Noon, B.R., \& Flather, C.H. 2005. Quantile regression reveals hidden bias and uncertainty in habitat model. Ecology, 86: 786- 800.

Dunham, J.B., Cade, B.S., \& Terrel, J.W. 2002. Influences of spatial and temporal variation on fish-habitat relationships defined by regression quantiles. Trans. Am. Fish. Soc., 131: 86- 98.

Eastwood, P.D., Meaden, G.J., \& Grioche, A. 2001. Modelling spatial variations I spawning habitat suitability for the sole Solea solea using regression quantiles and GIS procedures. Mar. Ecol. Prog. Ser., 224: 251- 266.

Eastwood, P.D., Meaden, G.J., Carpentier, A., \& Rogers, S.I. 2003. Estimating limits to the spatial extent and suitability of sole (Solea solea) nursery grounds in the Dover Strait. J. Sea Res., 50: 151- 165.

Eastwood, P.D. \& Meaden, G.J. 2004. Introducing greater ecological realism to fish habitat models. In: Nishida, T., Kalilola, P.J., \& Hollingworth, C.E. (eds.), GIS/ Spatial Analyses in Fishery and Aquatic Sciences (Vol. 2). Fishery-Aquatic GIS Research Group, Saitama, Japan, p. 181- 198.

Emerson, C.W., Grant, J., Mallet, A., \& Carver, C. 1994. Growth and survival of sea scallops Placopecten magellanicus: effects of culture depth. Mar. Ecol. Prog. Ser., 108: 119132.

Grant, J. 1996. The relationship of bioenergetics and the environment to the field growth of cultured bivalves. J. Exp. Mar. Biol. Ecol., 200: 239- 256.

Guisan, A. \& Zimmerman, N.E. 2000. Predictive habitat distribution models in ecology. Ecol. Model., 135: 147- 186.

Hardy, D. 1991. Scallop Farming. Fishing New Books, England, 237 pp.

Honda, S., Oshima, T., Nishimura, A., \& Hattari, T. 2004. Movement of juvenile walleye Pollock, Theragra chalcogramma, from a spawning ground to a nursery ground along the Pacific coast of Hokkaido, Japan. Fish. Oceanogr ., 13: 84- 98.

Hurvich, C.M. \&Tsai, C.- L. 1990. Model selection for least absolute deviations regression in small samples. Statistic \& Probability Letters, 9: 259- 265.

Inoue, J., Kawashima, M., Oshima, K.I., Fujiyoshi, Y., \& Maruyama, K-I., 2000. Winds fields over Funka Bay and their effect on water circulation in the bay. J. Oceanogr., 56: 507- 515.

Ito, H. 1991. Japan. In: Shumway, S. (ed.), Scallop: biology, ecology and aquaculture. Development in aquaculture and fisheries science, 21: 1,017-1,055.

Kafuku, T. \& Ikenoue, H. 1983. Modern methods of aquaculture in Japan. Development in aquaculture science 11 . Elsevier, Kodansha LTD, Tokyo, 216 pp.

Koenker, R. \& Hallock, K.F. 2001. Quantile Regression. J. Econ. Persp., 15: 143- 156.

Lovatelli, A. 1987. Status of scallop farming: a review of techniques. Network of Aquaculture Centres in Asia. NACA- SF/WP/87/ 1. Available at: http:// www.fao.org/ docrep/ field/ 003/ AB7 14E/ AB7 14E00.HTM, cited 7 April 2008. 
Lovatelli, A. 1988. Site selection for mollusc culture. Network of Aquaculture Centres in Asia. NACA-SF/WP/88/8. Available at: http:/ / www.fao.org/ docrep/ field/ 003/ AB722E/ AB722E00.htm, cited 7 April 2008.

MacDonald, B.A. \&Thompson, R.J. 1985. Influence of temperature and food availability on the ecological energetics of the giant scallop Placopecten magellanicus. I. Growth rates of shell and somatic tissue. Mar. Ecol. Prog. Ser., 25: 279- 294.

Maeno, K., Saitoh, S- I., Saitoh, K., \& Yoneta, K. 2002. An effect of coastal oyashio water and current on scallop farming. Fish. Sci. 68 supplement, 1901-1902. (tidak ada dalam naskah).

McClain, C.R. \& Rex, M.A. 2001. The relationship between dissolved oxygen concentration and maximum size in deep- sea turrid gastropods: an application of quantile regression. Mar. Biol., 139: 681- 685.

McClain, C.R. \& Crouse, J. 2006. Influence of ecological role on bathymetric patterns of deep-sea species: size clines in parasites gastropods. Mar. Ecol. Prog. Ser., 320: 161167.

Ohtani, K. 1971. Studies on the change of the hydrographic conditions in the Funka Bay II. Characteristics of the water occupying the Funka Bay. Bulletin of the Faculty of Fisheries, Hokkaido University, 22: 58- 66.

Ohtani, K., \& Kido, K. 1980. Oceanographic structure in Funka Bay. Bulletin of the Faculty of Fisheries, Hokkaido University, 31: 84- 114.

O'Reilly, J.E., Moritorena, S., Mitchell, B.G., Siegel, D.A., Carder, K.L., Garver, S.A., Kuhru, M., \& McClain, C. 1998. Ocean color chlorophyll algorithms for SeaWiFS. J. Geoph. Res., 103: 24937- 24953.

Peña, J.B., Canales, J., Adsuara, J.M., \& Sos, M.A. 1996. Study of seasonal settlements of five scallop species in the western Mediterranean. Aquacult. Int., 4: 253- 261.

Radiarta, IN. \& Saitoh, S- I. 2008. Satellite- derived measurements of spatial and temporal chlorophyll- a variability in Funka Bay, southwestern Hokkaido, Japan. Estuar. Coast. Shelf Sci., 79: 400- 408.
Shimada, H., Nishida, Y., Ito, Y., \& Mizushima, T. 2000. Relationship among growth and survival of cultured scallops (Patinopecten yessoensis JAY), and environmental condition in the coastal area off Yakumo, Funka Bay, Hokkaido, Japan. Scientific Report of Hokkaido Fisheries Experimental Station, 58: 49- 62 (in Japanese, with English Abstract).

Shimizu, M. \& Isoda, Y., 1997. The transport process of walleye pollock eggs into Funka Bay in winter. Bull. Japan. Soc. Fish. Oceanogr., 61: 134- 143 (in Japanese with English abstract).

Stead, S.M., Burnell, G., \& Goulletquer, P. 2002. Aquaculture and its role in integrated coastal zone management. Aquacul. Int., 10: 447- 468.

Takahashi, D., Nishida, Y., Uehara, K., \& Miyake, H. 2004. Dynamic and water mass structure of a summertime anticyclonic eddy in Funka Bay, Hokkaido, Japan. Estuar. Coast. Shelf Sci., 61: 185- 195.

Takahashi, D., Kido, K., Nishida, Y., Kobayashi, N., Higaki, N., \&Miyake, H. 2007. Dynamical structure and wind- driven upwelling in a summertime anticyclonic eddy within Funka Bay, Hokkaido, Japan. Cont. Shelf. Res., 27: 1928- 1946.

Tremblay, J. M. \& Sinclair, M. 1990. Sea scallop larvae Placopecten magellanicus on Georges Bank: vertical distribution in relation to water column stratification and food. Mar. Ecol. Prog. Ser ., 61: 1- 15.

Uki, N. 2006. Stock enhancement of the Japanese scallop Patinopecten yessoensis in Hokkaido. Fish. Res., 80: 62- 66.

Vaz, S., Martin, C.S., Eastwood, P.D., Ernande, B., Carpentier, A., Meaden, Geoff J., \& Coppin, F. 2008. Modelling species distribution using regression quantiles. J. Appl. Ecol., 45: 204- 217.

Ventilla, R.F. 1982. The scallop industry in Japan. Adv. Mar. Biol., 20: 309- 382.

Yu, K., Lu, Z., \& Stander, J. 2003. Quantile regression: applications and current research areas. Statistician, 52: 331- 350. 